Cultural Studies, vol. 25, núm. 3, 2011, pp. 432-438.

\title{
(Un)Thinking modernity and the burdens of difference.
}

\author{
Restrepo, Eduardo.
}

Cita:

Restrepo, Eduardo (2011). (Un)Thinking modernity and the burdens of difference. Cultural Studies, 25 (3), 432-438.

Dirección estable: https://www.aacademica.org/eduardo.restrepo/77 ARK: https://n2t.net/ark:/13683/ph6y/Tst

https://creativecommons.org/licenses/by-nc-nd/4.0/deed.es.

Acta Académica es un proyecto académico sin fines de lucro enmarcado en la iniciativa de acceso abierto. Acta Académica fue creado para facilitar a investigadores de todo el mundo el compartir su producción académica. Para crear un perfil gratuitamente o acceder a otros trabajos visite: https://www.aacademica.org. 
This article was downloaded by: [186.106.74.69]

On: 09 August 2011, At: 08: 50

Publisher: Routledge

Informa Ltd Registered in England and Wales Registered Number: 1072954 Registered office: Mortimer House, 37-41 Mortimer Street, London W1T 3J H, UK

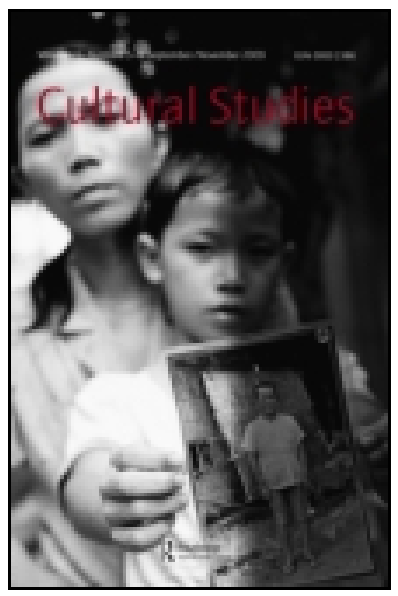

\section{Cultural Studies}

Publication details, including instructions for authors and subscription information:

http:/ / www. tandfonline.com/loi/ rcus20

\section{(UN)THINKING MODERNITY AND THE BURDENS OF DIFFERENCE}

Eduardo Restrepo

Available online: 24 Feb 2011

To cite this article: Eduardo Restrepo (2011): (UN)THINKING MODERNITY AND THE BURDENS OF DIFFERENCE, Cultural Studies, 25:3, 432-438

To link to this article: http:/ / dx. doi. org/ 10.1080/ 09502386. 2010.527157

\section{PLEASE SCROLL DOWN FOR ARTICLE}

Full terms and conditions of use: http://www.tandfonline.com/page/termsand-conditions

This article may be used for research, teaching and private study purposes. Any substantial or systematic reproduction, re-distribution, re-selling, loan, sub-licensing, systematic supply or distribution in any form to anyone is expressly forbidden.

The publisher does not give any warranty express or implied or make any representation that the contents will be complete or accurate or up to date. The accuracy of any instructions, formulae and drug doses should be independently verified with primary sources. The publisher shall not be liable for any loss, actions, claims, proceedings, demand or costs or damages whatsoever or howsoever caused arising directly or indirectly in connection with or arising out of the use of this material. 


\title{
Eduardo Restrepo
}

\section{(UN)THINKING MODERNITY AND THE BURDENS OF DIFFERENCE}

\section{A response to Escobar's paper 'Latin America at a Crossroads'}

\begin{abstract}
At the beginning of his paper, Escobar states 'How one thinks about these processes is itself an object of struggle and debate, and it is at this juncture that this paper is situated'. He acknowledges the fact that the transformations that have taken place in Latin America, more so than in other situations, require that we take on certain emphases and premises. For my brief response, I do not intend to produce a close analysis of his specific interpretation of the three countries around which the entire discussion is carried out. In this sense, rather than engage in a serious dialogue with the empirical materials that support his interpretation of Bolivia, Ecuador and Venezuela, my comments will be directed at the more general aspects of certain premises that are part of the grid of intelligibility through which such interpretations are stated.
\end{abstract}

\section{A hermeneutics of hope}

Escobar's article is quite explicit when it comes to stating a political will to knowledge and its profound effects in constituting our understanding of the world (and therefore how we can go about changing it). According to Escobar 'the questions of where one thinks from, with whom, and for what purpose become themselves important elements of the investigation; this also means that the investigation, more than ever, is simultaneously theoretical and political'. Even though Escobar does not explicitly reveal the place from which he is speaking, with whom he is speaking or for what purpose, the reader can, from his interpretations, deduce a commitment to the practices of difference and place that are embodied by indigenous and Afro descendant movements and communities in Latin America (who would also be part of his interlocutors). This has the purpose of disrupting the place that capitalism, Euro modernity and the State hold in theoretical and political imaginations, thereby making it so that other worlds are possible. 
I find myself to be in complete agreement with Escobar in his claim that in any investigation or interpretation, questions of the place from which one is thinking, the people one is speaking with, and one's purpose, are of vital importance. Within cultural studies, such questions are fundamental to what Stuart Hall (1992) has called the political vocation of cultural studies. As both feminist and post-colonial theory have argued in many ways, knowledge is not only situated, but it is the battleground of innumerable disputes and its effects are constitutive of the world. To put it in simpler terms, the manner in which the world is interpreted is inherently political as it plays a crucial role in maintaining or undermining the ways in which we inhabit and intervene in the world.

Escobar's interpretations place the emphasis on how hopeful certain positions and emergences can be. An optimism of the intellect (to use an inverted version of the first part of Gramsci's maxim) seems to be propelling not only his interpretation of Latin America's current conjuncture, but also the manner in which he comes to understand how knowledge is both situated and performative. Thus, this optimism of the intellect can also be referred to as a hermeneutics of hope.

There are two different aspects involved in this hermeneutics of hope. On the one hand, one of the most important parts of intellectual work is its capacity to make what is only possible or emergent into something that is real and that becomes a part of social life. An intellectual's work cannot simply imply being a cartographer of that which already exists at a particular point in time; he or she must be a cartographer of the emergent, of the possible that is becoming. A cartography of the possible, of the virtual, or even of the nonvisible, is a immanent part of the struggle towards consolidating certain social worlds. On the other hand, this hermeneutics of hope is part of a 'regime of truth' that does not fit with the one that has shaped most academic orientated work. From the perspective of this hermeneutics of hope, the 'regime of truth' of academic work is both logocentric and Eurocentric, and therefore rejects and ignores 'other forms of knowledge' that are not based exclusively on 'reason' and 'Western' science. Hence, the 'regime of truth' that operates in the hermeneutics of hope is founded upon 'other' epistemologies, many of them in the form of corporalities and oralities that have been shaped into practices of and struggles over difference.

Even though I appreciate the value and urgency of this hermeneutics of hope, the implications of Gramsci's 'pessimism of the intellect and optimism of the will' cannot be left aside when it comes to interpreting Latin America's current conjuncture. To hold on to a pessimism of the intellect implies recognizing the fact that intellectual work is all about understanding, in the most dense way, with the best conceptual tools that are available to us, and with the best empirical foundation that we can get, the ties and mechanisms that keep the world from being the way we want to be. 
Intellectual work must take on the non-negotiable and urgent challenge of not obliterating the fact that the world is contradictory, earthly and multiple, on behalf of angel-like representations of what we would like that world to be. The world's materiality imposes and insists, regardless of whether we like it or not, or whether we understand it (or not) conceptually or existentially. Yet if our purpose is to try and transform the miseries that come from this materiality, we cannot simply set a principle of intelligibility that does not take seriously into account that materiality. Stuart Hall has reminded us, quite wisely, that theory matters because bad theory usually leads to bad politics. It is for this reason that intellectual work - in Gramsci's sense of a function and an articulation with concrete historical forces - cannot allow itself to assume that any conceptualization of the world is equally relevant when what is at stake is something like a post-capitalist political project. The point is not an epistemic relativism, nor the celebratory embrace of any (epistemological and political) difference.

Now, given Latin America's most recent conjuncture, a pessimism of the intellect implies coming up with genealogies and ethnographies of the emergent, but also of the dominant and residual (to put it in Williams' words), as well as to provide contextual evidence of the re-articulations of political subjects and subjectivities that are at play and that bring about forms of empowerment but also, precisely because of this, forms of subjection. The historicity that embodies us and at the same time blinds us, is precisely the place where we should focus our intellectual efforts in order to de-naturalize the political and theoretical imaginary that may appear to us, at the moment, as a progressive predicament. Optimism of the will, which is the second part of Gramsci's maxim, without which it would lose all its force, implies taking part in the struggles that matters for us because, by identification or position, they are our own.

In sum, given the fact that the world is not produced simply by the will and by good intentions (which might lead us to a voluntaristic and naive vision of social life and power), we cannot afford to not understand, in the most dense possible way, the conditions and articulations of agencies at stake in a particular juncture, their multiple genealogies and radical historicities; in one word, we cannot give up radical contextualism which is one of the most important legacies of cultural studies (Grossberg 2006).

\section{Disrupting the political and theoretical imagination}

Escobar's invitation to conceive a post-capitalist, post-liberal, post-state world, meaning by that a world in which capitalism, liberalism (Euro-modernity) and the state are not the center and limit of our theoretical and political imaginations, is quite suggestive. In this sense, his evaluation of the emergent 
processes that have been taking place in Latin America and that embody such projects of disruption, deems them as quite hopeful. Given the nightmares of neo-liberalism and postmodernism's cynicism, Escobar's article is quite refreshing. I wonder, however, whether the terms in which the analysis is stated ought to be further elaborated.

According to Escobar, when it comes to post-capitalism, we ought to give the multiplicity of economic and non-economic proposals and practices a more prominent position and make them more visible (this includes a diversity of capitalisms, alternative capitalisms and non-capitalist practices). By doing this, we would seek to disrupt capitalism's position as the hegemonic form of economy. Though I am politically in tune with his post-capitalist proposal, I believe that an appeal to practices of difference (both economic and noneconomic) is necessary but not sufficient. Capitalism (as a social relation of production, but also as social and economic formations and as a world-system) has always dwelled in heterogeneity. Capitalism as a relationship and as a system, rather than erase differences, takes advantage of them and constitutes them (Laclau 1978). Aníbal Quijano (2000) has suggested the concept of historical structural heterogeneity precisely to be able to account for the manner in which the relations of labor, nature, gender, subjectivity and authority that are produced in different horizons of historicity, are articulated. It is a historical articulation that is constituted on the basis of a predominance of one type of power relation, which produces the effect of a (non-closed) totality. If Quijano's characterization is correct, as I believe it is, the emergence of post-capitalism would take more than just making practices of difference in the abstract more visible and better positioned. In order for postcapitalism to become a reality, to come into existence (both at the level of concrete national formations and of the world-system), a certain predominance must be re-articulated that cannot but imply a positive content that is actually concrete such as solidarity or reciprocity. It is not just difference but particular differences that need to operate in a predominant place.

When it comes to post-liberalism, I do not follow Escobar's line of argument in which he intends to superimpose it with a disruption of Euromodernity. Even if we can consider liberalism to be part of Euro-modernity, we cannot reduce Euro-modernity to liberalism. This would imply, for example, that Marxism can also be reduced to liberalism. We also cannot establish an identity between Euro-modernity and Eurocentrism, or even less so, between Euro-modernity and tendencies that celebrate modernity. This leads me to think that post-liberalism may not be the most adequate name for what Escobar has in mind, which is a disruption of Euro-modernity as the guiding paradigm of social and political life.

But let us take a look at what is really behind all this for a moment. In his argument, Escobar characterizes Euro-modernity (and at times just modernity) on the basis of its dualist ontology, which in addition to having effects on how the natural world is conceived and intervened into, has also established 
relations that subordinate other human beings, their ways of life and their epistemologies (coloniality). This is where the arrogance of the imposition of the universalism of modernity come from. I agree with Escobar's position that Latin American elites' appeal to 'modernity' as a civilization project, in whose name humans (populations), non-humans (nature), and our selves (subjectivities) have been governed, ought to be questioned. Nevertheless, I disagree with his characterization of Euro-modernity (as well as of alternative modernities and alternatives to modernity), as I believe that it is trapped in what I would like to call hyperreal modernity: to try and identify a concrete or abstract content of modernity that provides it with an identity and a substantive coherence, makes it radically different from what is not modernity, and that establishes, once and for all, its inside and outside, and its before and after, is a most clear expression of a hyperreal modernity. ${ }^{1}$ In my point of view, Escobar's claims (those regarding modernity as well as those regarding alternative modernities and alternatives to modernity) would greatly benefit from a perspective of eventalization (in Foucault's sense) or ethnography [such as that suggested by Inda (2005)] that would allow us to understand the reasons, technologies and subjectivities that are articulated in the name of modernity in a concrete and context-based manner.

\section{Relational ontologies and practices of difference}

The end of Escobar's article presents what he understands as relational ontologies. He presents this concept by setting it in stark contrast with modern ontology: 'Relational ontologies are those which eschew the divisions between nature and culture, individual and community, us and them that are central to the modern ontology (that of liberal modernity).' According to Escobar, these relational ontologies raise questions about modern politics and theory because of their 'pervasive binarism, and the reduction of complexity.' Practices of difference are both the source and the expression of these relational ontologies.

I understand the relevance of these relational ontologies and the appeal to practices of difference. A world where there is a place for many worlds, a pluversality as an epistemic and political horizon, is a valuable principle that Escobar adequately highlights in his analysis of social movements and political transformations in Latin America's current conjuncture. As a counterpoint to this line of argument, however, I wonder about the usefulness of a view of the world from two types of ontologies that are clearly opposite (one is dualist non-relational and simplistic while the other is non-dualist relational and complex). This kind of position seems to operate in the same binary framework within which there is a sameness that erases difference, and an otherness that fosters that difference. There are several passages in which Escobar insists that the issue is more complex and that he is not thinking about 
purities or contrasts like these. One cannot avoid the feeling, however, that the argument needs to be more carefully constructed.

The idea of these relational ontologies seems to be attributed to some populations (indigenous and Afro descendant), and that brings to my mind ideas such as Pierre Bourdieu's concept of the 'real as relational' and the work of Bruno Latour that shows that 'we (Europeans) have never been modern' (precisely because practices of hybridization, mediation and translation make practices of purification highly problematic). Both of them seem to be operating in a non-dualistic ontology, yet they cannot be more modern. It also reminds me of how the European imperial imagination has always conceived of its differences with non-Europeans as something at the ontological level (as Said (1978) wonderfully shows in Orientalism). So, appealing to a unique and radical ontological distinction between 'them' and 'us' (whatever inversion of the connotation we are trying to introduce) might involve dense historical imaginations and power relationships, rather than simply efforts to problematize and disrupt them.

In my view, the main point that Escobar's article brings forth, beyond what he may say about Latin America's current conjuncture, can be summed up in the following question: how are we (un)thinking modernity and what are the burdens of difference?

\section{Note}

1 This notion of hyperreal modernity is inspired in the work of Alcida Ramos (who suggests the term hyperreal Indian) and Dipesh Chakrabarty (who talks about a hyperreal Europe or India). Hyperreal refers to an abstract normative structuring definition of the theoretical and political imagination, a 'master signifier' that has been generally naturalized from which that which can be thought is organized but that is always excluded from what is thought.

\section{References}

Escobar, A. (2010) 'Latin America at a crossroads. Alternative modernizations, post-liberalism, or post-development?', Cultural Studies, vol. 24, no. 1, pp. $1-65$.

Grossberg, L. (2006) 'Does cultural studies have futures? Should it? (or What's the matter with New York?). Cultural studies, contexts and conjunctures', Cultural Studies, vol. 20, pp. 1-32.

Hall, S. (1992) 'Cultural studies and its theoretical legacies', in Cultural Studies, eds L. Grossberg, C. Nelson \& P. Treichler, New York, Routledge, pp. 277-294. 
Inda, J. X. (2005) 'Analytics of the modern: an introduction', in Anthropologies of Modernity: Foucault, Governmentality, and Life Politics, ed. J. X. Inda, Malden, MA, Blackwell Publishing, pp. 1-20.

Laclau, E. (1978) Política e ideología en la teoría marxista: capitalismo, fascismo, populismo, México City, Siglo XXI Editores.

Quijano, A. (2000) 'Colonialidad del poder y clasificación social', Journal of WorldSystem Research, vol. 2, pp. 342-386.

Said, E. (1978) Orientalism, New York, Pantheon Books. 